\title{
Physical Characteristics of Korean Red Pines According to Provinces (Goseong, Hongcheon and Bonghwa-gun) $)^{1}$
}

\author{
Min-Ji $\mathrm{Kim}^{2} \cdot$ Byung-Ro Kim ${ }^{3, \dagger}$
}

\begin{abstract}
Physical characteristics of Korean red pine (Pinus densiflora) were investigated with different cultivation locations in Taebaek Mountains as Goseong-gun, Hongcheon-gun and Bonghwa-gun as experimental sites. Moisture content based on air-dried or green (artificial) wood was no significant differences with different cultivation places. Specific gravities of both sapwood and heartwood of red pine from Bonghwa-gun were higher than those from other two sites (Hongcheon-gun or Goseong-gun). Specific gravity of heartwood of red pine from Goseong-gun was higher than it from Hongcheon-gun, but this trend was opposite in case of sapwood. Higher specific gravity of red pine heartwood from Goseong-gun maybe resulted in higher strength than those of other sites. In shrinkage ratio, there was no significant difference among different cultivation places in radial directions, but red pine from Bonghwa-gun was higher than those of other sites in tangential directions. Hygroscopicity was no significant differences with different cultivation places. These results will be helpful information for efficient use of pinewood and good quality of pinewood production for genetical breeding improved.
\end{abstract}

Keywords: Korean red pine (Pinus densiflora), different cultivation locations, moisture contents, specific gravity, shrinkage ratio, hygroscopicity

\section{INTRODUCTION}

Korean red pine trees have excellent quality (physical and mechanical properties) and are representative species of Korea that have been used in palaces, temples, houses, furniture, ships and so on. As the most favorite tree of our people, it has been revealed that $71 \%$ of architectures in Goryo era, $73 \%$ of architectures in mid-Joseon era, and $88 \%$ of architectures in late-Joseon era were constructed using them (Park et al., 2007).

As the properties of pine trees vary depending on the production region (Han et al., 2015), for more efficient use of pine trees and the superior breeding of them, it would be necessary to investigate the reasons for the different properties depending on the production region. The investigation of differences in properties will first be on anatomical, physical and mechanical ones.

In this study, we selected three regions, Yeongdong (Goseong-gun), Yeongseo (Hongcheon-gun) and Yeongnam (Bonghwa-gun), representative pine tree production regions in Korea to get samples, and an

\footnotetext{
${ }^{1}$ Date Received May 14, 2018, Date Accepted August 6, 2018

${ }^{2}$ Forest Products Department, National Institute of Forest Science, Seoul 02455, Republic of Korea

${ }^{3}$ Department of Wood and Paper Science, Chungbuk National University, Cheongju 28644, Republic of Korea

† Corresponding author: Byung-Ro Kim (e-mail: brkim@cbnu.ac.kr, ORCID: 0000-0001-5800-2058)
} 
anatomical research was conducted to determine differences between the length and the diameter of the tracheid. And it was revealed that there were differences in the length and the diameter of the trachied (Kim et al., 2018).

Therefore, in this study, the purpose of this study was to investigate the difference of physical properties following the study of the anatomical characteristics (Kim et al., 2018) of the Korean pine in the previous paper by regional groups, and the physical properties of lumber are basically attributable to their anatomical properties so that their anatomical properties are also reviewed.

\section{MATERIALS and METHODS}

\subsection{Materials}

For this study, we received a pine tree from Yeongdong (Goseong-gun), Yeongseo (Hongcheon-gun) and Yeongnam (Bonghwa-gun), respectively in 2015.
They were originally possessed by the East Sea Timber Distribution Center of Forest union. The thickness of the discs were about $20 \mathrm{~cm}$ and the no. of tree rings, chest diameter, mean ring width, and latewood proportion at the time of receipt are shown in Table 1 (Kim et al., 2018) and sampling is shown in Fig. 1 (Park et al., 2015). In addition, for the comparison of the same year and area, the year of harvesting was estimated using the annual-ring method, which was analyzed as 2014 for Goseong, 2012 for Hongcheon, 2014 for Bonghwa (Kim et al., 2018).

\subsection{Methods}

\subsubsection{Moisture content}

The water content of trees of each production site was measured as green moisture content (artificial) and air-dry moisture content. For the measurement of green moisture content, as about 1 3 years has passed after harvesting, samples were immersed in distilled water until there was no difference in weight.

Table 1. Information on experimental samples

\begin{tabular}{ccccc}
\hline Province* & No. of Tree rings & $\begin{array}{c}\text { Diameter } \\
(\mathrm{cm})\end{array}$ & $\begin{array}{c}\text { Average of ring widths } \\
(\mathrm{mm})\end{array}$ & $\begin{array}{c}\text { Latewood proportion } \\
(\%)\end{array}$ \\
\hline \hline Goseong-gun (G) & 85 & 48 & 3.1 & 22.87 \\
Hongcheon-gun(H) & 82 & 42 & 2.6 & 20.19 \\
Bonghwa-gun (B) & 76 & 46 & 3.1 & 18.57 \\
\hline
\end{tabular}
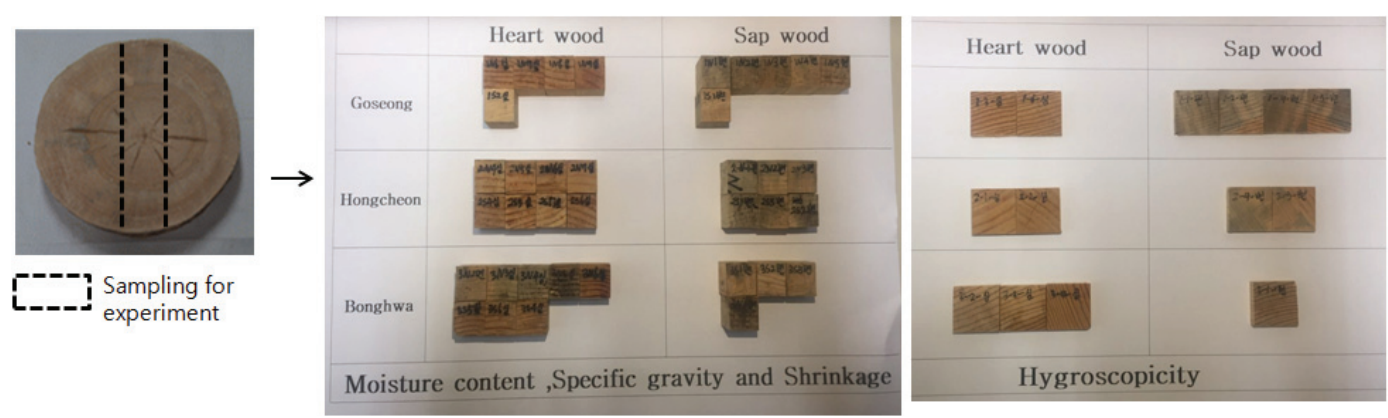

Fig. 1. Sample cutting image. 
Physical Characteristics of Korean Red Pines According to Provinces (Goseong, Hongcheon and Bonghwa-gun)

The size of the specimens from each tree production region was $2 \mathrm{~cm}(\mathrm{~T}) \times 2 \mathrm{~cm}(\mathrm{R}) \times 2 \mathrm{~cm}(\mathrm{~L})$ in size and $5 \sim 8$ pieces of heartwood and $4 \sim 6$ pieces of sapwoodspecimens were taken, respectively (Fig. 1). The preparation and measurement of the specimen was in accordance with KS F 2199 (2001).

\subsubsection{Specific gravity}

The specific gravity of each tree production region was measured based on green, air-dry, and oven-dry specific gravity. The size of the specimen was $2 \mathrm{~cm}$ $(\mathrm{T}) \times 2 \mathrm{~cm}(\mathrm{R}) \times 2 \mathrm{~cm}(\mathrm{~L})$ square. At this time, they were classified as heartwood $(5 \sim 8)$ and sapwood $(4 \sim 6)$ (Fig. 1). The preparation and measurement of the specimen was in accordance with KS F 2198 (2001).

\subsubsection{Shrinkage}

The shrinkage of each tree production region was measured based on air-dry shrinkage and total shrinkage. The specimen was produced consecutively from the number of the square with dimensions of 2 $\mathrm{cm}(\mathrm{T}) \times 2 \mathrm{~cm}(\mathrm{R}) \times 2 \mathrm{~cm}(\mathrm{~L})(11 \sim 14$ units). In order to measure the length of the specimen, a line in the radial and tangential directions was drawn on the cross section using a vernier caliper (Fig. 1). The specimen preparation and measurement methods are in accordance with KS F 2203 (2004).

\subsubsection{Hygroscopicity}

In order to measure the hygroscopicity of each tree production region, 4 6 specimens were prepared with the size of $3 \mathrm{~cm}(\mathrm{~T}) \times 3 \mathrm{~cm}(\mathrm{R}) \times 0.5 \mathrm{~cm}(\mathrm{~L})$ and taken consecutively from trees. At the time of preparation, the two sides were straight grained rectangular parallelepiped with the short axis parallel to the direction of the fiber (Fig. 1). The samples were humidified in a constant temperature and humidity (LHT-2250C, LabTech,Korea) to the temperature of $40^{\circ} \mathrm{C}$, relative humidity of $75 \% / 40^{\circ} \mathrm{C}$, and relative humidity of $90 \%$, until there was no weight change. The specimen preparation and measurement method is in accordance with KS F 2205 (2004).

\section{RESULTS and DISCUSSION}

\subsection{Moisture content and specific gravity}

Table 2 shows the air-dry moisture content and green moisture content of pine trees in Goseong-gun, Hongcheon-gun, and Bonghwa-gun. The air-dry moisture content in the heartwood part was $13.7 \%$ in Goseong-gun pine, Hongcheon-gun pine 12.4\%, and Bonghwa-gun pine $13.9 \%$. For sapwood part, Goseonggun pine $14.0 \%$, Hongcheon-gun pine $12.5 \%$, and Bonghwa-gun pine $13.8 \%$, respectively. The green moisture content was $71.4 \%$ for Goseong-gun pine,

Table 2. Moisture content of wood produced in each province

\begin{tabular}{ccccc}
\hline Condition & Province & Goseong-gun & Hongcheon-gun & Bonghwa-gun \\
\hline \hline $\begin{array}{c}\text { Air-dry } \\
\text { moisture content }\end{array}$ & Heartwood(\%) & $13.7 \pm 0.3$ A* & $12.4 \pm 0.4 \mathrm{~A}$ & $13.9 \pm 1.3 \mathrm{~A}$ \\
\hline $\begin{array}{c}\text { Artificial green } \\
\text { moisture content }\end{array}$ & Heartwood(\%) & $71.4 \pm 30.9 \mathrm{~A}$ & $76.9 \pm 10.2 \mathrm{~A}$ & $90.9 \pm 27.9 \mathrm{~A}$ \\
\hline
\end{tabular}

* The same letters indicate no significant difference by Duncan's multiple test at 0.05 level. Heartwood = Capital letter, Sapwood $=$ Small letter. 
Min-Ji Kim • Byung-Ro Kim

Table 3. Specific gravity of wood produced in each province

\begin{tabular}{ccccc}
\hline Condition & Province & Goseong-gun & Hongcheon-gun & Bonghwa-gun \\
\hline \hline $\begin{array}{c}\text { Oven dry specific } \\
\text { gravity(wo/vo) }\end{array}$ & Heartwood & $0.45 \pm 0.04 \mathrm{~A} *$ & $0.40 \pm 0.02 \mathrm{~B}$ & $0.46 \pm 0.02 \mathrm{~A}$ \\
\hline $\begin{array}{c}\text { Air dry specific } \\
\text { gravity(wo/va) }\end{array}$ & Sapwood & $0.37 \pm 0.02 \mathrm{c}$ & $0.41 \pm 0.01 \mathrm{~b}$ & $0.45 \pm 0.02 \mathrm{a}$ \\
\hline $\begin{array}{c}\text { Artificial green } \\
\text { moisture content(wo/vg) }\end{array}$ & Seartwood & $0.47 \pm 0.03 \mathrm{~A}$ & $0.42 \pm 0.02 \mathrm{~B}$ & $0.49 \pm 0.02 \mathrm{~A}$ \\
\hline
\end{tabular}

* The same letters indicate no significant difference by Duncan's multiple test at 0.05 level. Heartwood = Capital letter, Sapwood $=$ Small letter.

76.9\% for Hongcheon-gun pine, 90.9\% for Bonghwagun pine for heartwood part, and $166.7 \%$ for Goseonggun pine, $134.4 \%$ for Hongcheon-gun pine, and $110.3 \%$ for Bonghwa-gun pine for sapwood part.

In the Duncan test for differences between the tree production regions, the air-dry moisture content was $12.5 \%$ for Hongcheon-gun pine, which is smaller than $14.0 \%$ for Goseong-gun pine and $13.8 \%$ for Bonghwagun pine in sapwood. And it was revealed that there are no difference in the regions in terms of air-dry moisture content of heartwood and green moisture content of heartwood and those of sapwood.

The green moisture content revealed by study conducted by Jo et al. (1982) was 84\%for Korean nut pine, $94 \%$ for pine tree, $91 \%$ for Japanese black pine tree, and $91 \%$ for red pine tree, regardless of whether it is heartwood or sapwood. These values are similar to the artificial green moisture content of the heartwood part used in this study. Kang et al. (2008) reported that the green moisture content varies widely depending on the species of trees,but the green moisture content of most species is $30-200 \%$. In Korea, the average air-drymoisture content is reported to be $14.2 \%$ in the case of moisture-proof and $13.2 \%$ in the case of moisture absorption. Kim et al. (2008) found that air-dry moisture content was $12.7 \%$ for sapwood of pine wood in Jeonbuk Muju area, $10.3 \%$ for sapwood. And 10.9\% for heartwood and $10.7 \%$ for sapwood in Anmyeongdo pine trees. Compared to this study, the pine trees of Goseong, Hongcheon, and Bonghwa-gun showed higher air-dry moisture content than those of Muju and Anmyeongdo pines.

Table 3 shows the oven-dry, air-dry and green specific gravity of Goseong-gun, Hongcheon-gun and Bonghwagun. For the oven-dry specific gravity, Goseong-gun pine was 0.45 , Hongcheon-gun pine 0.40, Bonghwa-gun pine 0.46 for heartwood part, and Goseong-gun pine was 0.37 , Hongcheon-gun pine 0.41 and Bonghwa-gun pine 0.45 . for sapwood part. Statistically, Goseong-gun and Bonghwa-gun pine trees showed that they are high in the heartwood part and Hongcheon-gun pine tree was low. Bonghwa-gun pine showed highest, followed by Hongcheon-gun pines, and Goseong-gun pines for sapwood part. For the air-dry specific gravity, Goseonggun pine was 0.47, Hongcheon-gun pine 0.42, Bonghwagun pine 0.49 , respectively. For sapwood part, Goseonggun pine was 0.40 , Hongcheon-gun pine 0.44 and Bonghwa-gun pine 0.48 , respectively. Statistically, in the heartwood part, Goseong-gun and Bonghwa-gun pine trees showed high as same with oven-dry specific gravity and Bonghwa-gun pine tree showed high in sapwood part. For the green specific gravity, Goseonggun pine was 0.48, Hongcheon-gun pine 0.44, Bonghwagun pine 0.54 , for heartwood part. For sapwood part, Goseong-gun pine was 0.42, Hongcheon-gun pine 0.46, Bonghwa-gun pine 0.51, respectively. Statistically, 
Physical Characteristics of Korean Red Pines According to Provinces (Goseong, Hongcheon and Bonghwa-gun)

Bonghwa-gun pine was the highest in the heartwood part, while Goseong-gun and Hongcheon-gun pine showed no difference. Bonghwa-gun pine was the highest in sapwood, followed by Hongcheon-gun and Goseong-gun pine. Overall, the Bonghwa-gun pine trees were higher than the two other tree production regions in the heartwood section, and the gap was prominent for the sapwood part. Goseong-gun pine trees were higher in the heartwood part while Hongcheon-gun were higher in sapwood part. However, the specific gravity of the Goseong-gun pine tree which showed high in heartwood part can be higher. Therefore, Goseong-gun pine tree with high specific gravity of heartwood part can be expected to be stronger than Hongcheon-gun pine tree as a whole. Kim et al. (2008) reported that the air-dry specific gravity (heartwood, sapwood) and green specific gravity (heartwood, sapwood) of pine trees in Muju, Jeonbuk Province were $0.49,0.43$ and 0.40, 0.40, and 0.44, 0.45 and 0.40, 0.40 for Anmyeondo pine tree, and $0.45,0.45$, and $0.51,0.45$ for Chunyang pine, respectively. The air-dry specific gravity of the pine tree was reported to be 0.47 , and the oven-dry specific gravity 0.44 in the study of Jung et al. (2008) on Korean useful wood. In addition, Cho (1994) reported that green specific gravity of pine trees is 0.70 and air-dry specific gravity 0.47 . Green specific gravity is considered the green weight, therefore the green specific gravity (oven-dry mass) in this study will be difficult to compare with. These reports showed values similar to those of Goseong and Hongcheon area.

\subsection{Shrinkage}

Table 4 shows air-dry shrinkage, total shrinkage and $\mathrm{T} / \mathrm{R}$ ratio of pine trees in Goseong-gun, Hongcheon-gun and Bonghwa-gun. In the tangential direction of air-dry shrinkage, Goseong-gun pine was 2.86\%, Hongcheongun pine 3.94\% and Bonghwa pine 4.39\%. In radial direction, Goseong-gun pine was 1.73\%, Hongcheongun pine $2.09 \%$ and Bonghwa-gun pine 2.29\%, respectively. The $\mathrm{T} / \mathrm{R}$ ratio was measured to be $1.67 \%$ for Goseong-gun pine, 1.89\% for Hongcheon-gun pine, and $1.92 \%$ for Bonghwa-gun pine. For the tangential direction of the total shrinkage, Goseong-gun pine was $6.32 \%$, Hongcheon-gun pine $6.58 \%$ and Bonghwa-gun pine $9.85 \%$, respectively. And for the radial direction, Goseong-gun pine was $2.83 \%$, Hongcheon-gun pine $3.44 \%$, and Bonghwa-gun pine 3.68\%. The T/R ratio was $2.11 \%$ for Goseong-gun pine, $1.04 \%$ for Hongcheon-gun pine, and 2.68\% for Bonghwa-gun pine tree. The result of the Duncan test to determine differences between the tree production regions revealed that Hongcheon-gun pine and Bonghwa-gun pine trees showed high tangential air-dry shrinkage. Bonghwa-gun pine trees were high in the total shrinkages while there was no difference between the tree production regions

Table 4. Shrinkage of wood produced in each province

\begin{tabular}{|c|c|c|c|c|c|c|}
\hline \multirow[b]{2}{*}{ Position } & \multicolumn{2}{|c|}{ Goseong-gun } & \multicolumn{2}{|c|}{ Hongcheon-gun } & \multicolumn{2}{|c|}{ Bonghwa-gun } \\
\hline & Air dry & Oven dry & Air dry & Oven dry & Air dry & Oven dry \\
\hline Tangential(\%) & $\begin{array}{c}2.86 \mathrm{~B}^{*} \\
\pm 1.45\end{array}$ & $\begin{array}{c}6.32 \mathrm{~b} \\
\pm 2.94\end{array}$ & $\begin{array}{c}3.94 \mathrm{~A} \\
\pm 0.79\end{array}$ & $\begin{array}{c}6.58 \text { b } \\
\pm 1.28\end{array}$ & $\begin{array}{c}4.39 \mathrm{~A} \\
\pm 0.86\end{array}$ & $\begin{array}{c}9.85 \mathrm{a} \\
\pm 4.12\end{array}$ \\
\hline Radial(\%) & $\begin{array}{c}1.73 \mathrm{~A} \\
\pm 0.81\end{array}$ & $\begin{array}{c}2.83 \text { a } \\
\pm 0.90\end{array}$ & $\begin{array}{c}2.09 \mathrm{~A} \\
\pm 0.92\end{array}$ & $\begin{array}{c}3.44 \text { a } \\
\pm 1.40\end{array}$ & $\begin{array}{c}2.29 \mathrm{~A} \\
\pm 0.63\end{array}$ & $\begin{array}{c}3.68 \text { a } \\
\pm 0.52\end{array}$ \\
\hline $\mathrm{T} / \mathrm{R}$ & 1.67 & 2.11 & 1.89 & 1.04 & 1.92 & 2.68 \\
\hline
\end{tabular}

\footnotetext{
* The same letters indicate no significant difference by Duncan's multiple test at 0.05 level. Air dry = Capital letter,
} Oven dry $=$ Small letter. 


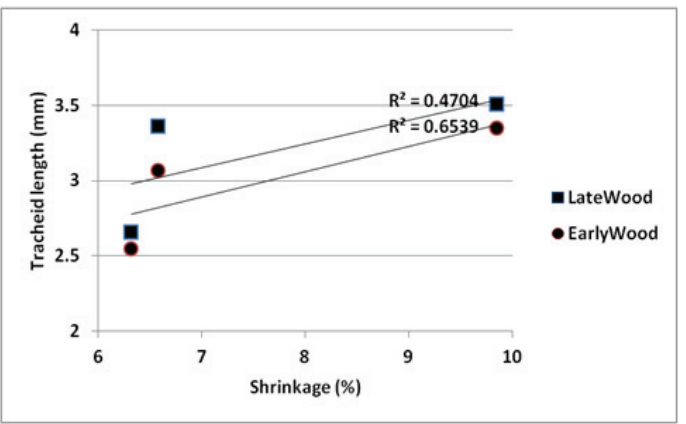

Fig. 2. Relationship between tracheid length and shrinkage (Tangential direction).

for radial direction.

Fig. 2 shows the relationship between tracheid length (Kim et al., 2018) and shrinkage in three tree production regions. In the figure, shrinkage and tracheid length were found to be proportional. Kim et al. (1998), Hiller (1964), Mark (1967), Preston (1952), Wellwood (1962), and Wadanabe et al. (1964) reported that the tracheid length was negatively correlated with the microfibril angle. In other words, the longer the tracheid length, the smaller the microfibril angle and the shorter the tracheid length, the larger the microfibril angle. Barber et al. (1964) reported that shrinkage in fiber direction increased with increasing micro fibril angle, while lateral shrinkage decreased with decreasing microfibril angle. In this study, it is thought that the larger shrinkage in the lateral shrinkage in Bonghwa-gun pine trees is due to the longer tracheid length. In order to prove this further, the investigation of these microfibril angles would be necessary in the future.
Kim et al. (2008)'s study revealed that the T/R ratio of Anmyeondo pine is 2.91. The $\mathrm{T} / \mathrm{R}$ ratio of Anmyeondo pine was higher than those of Goseonggun, Hongcheon-gun and Bonghwa-gun when compared with this study. In the study of Cho (1994), the pine shrinkage was $4.88 \%$ in the radial direction, $9.11 \%$ in the tangential direction, and $0.31 \%$ in the fiber direction in the total shrinkage. The shrinkage in radial direction was higher than the three regions and the tangential was higher than those of Goseong-gun and Hongcheongun and lower than Bonghwa-gun pine trees. The air-dry shrinkage was $2.97 \%$ in the radial direction, $5.40 \%$ in the tangential direction, and $0.16 \%$ in the fiber direction, showing higher values than those from three regions.

\subsection{Hygroscopicity}

Table 5 shows the hygroscopicity of pine trees in three areas: Goseong-gun, Hongcheon-gun and Bonghwagun. For hygroscopicity for each region at $40{ }^{\circ} \mathrm{C}$ and $75 \%$ relative humidity, $13.0 \%$ for Goseong-gun pine, $13.0 \%$ for Hongcheon-gun pine, and $13.3 \%$ for Bonghwa-gun pine, respectively. And hygroscopicity at $40{ }^{\circ} \mathrm{C}$ and $90 \%$ relative humidity showed little difference between tree production regions, with $16.9 \%$ for Goseong-gun pine, 16.7\% for Hongcheon-gun pine, and $16.9 \%$ for Bonghwa-gun pine, respectively. Haishi et al. (1973) studied the equilibrium moisture content of major Japanese species ranging from 9.7 to $13.7 \%$ at a relative humidity of $75 \%$ and a temperature of $40{ }^{\circ} \mathrm{C}$, with an average of $12.3 \%$ for heartwood and

Table 5. Hygroscopicity of wood produced in each province

\begin{tabular}{cccc}
\hline & Province & Goseong-gun & Hongcheon-gun \\
\hline \hline $40^{\circ} \mathrm{C}, 75 \% \mathrm{RH}(\%)$ & $13.0 \pm 0.2 \mathrm{~B}^{*}$ & $13.0 \pm 0.3 \mathrm{~B}$ & $13.3 \pm 0.1 \mathrm{~A}$ \\
$40^{\circ} \mathrm{C}, 90 \% \mathrm{RH}(\%)$ & $16.9 \pm 0.4 \mathrm{a}$ & $16.7 \pm 0.3$ a & $16.9 \pm 0.4$ a \\
\hline
\end{tabular}

* The same letters indicate no significant difference by Duncan's multiple test at 0.05 level. $40{ }^{\circ} \mathrm{C}, 75 \% \mathrm{RH}=\mathrm{Capital}$ letter, $40^{\circ} \mathrm{C}, 90 \% \mathrm{RH}=$ Small letter. 
Physical Characteristics of Korean Red Pines According to Provinces (Goseong, Hongcheon and Bonghwa-gun)

an average 12.4 for sapwood, and $14.4 \sim 19.2 \%$ at $90 \%$ relative humidity, $17.4 \%$ for heartwood and $17.8 \%$ for sapwood. Domestic pine trees were higher in average hygroscopicity than major species of trees in Japan. Park et al. (2016) reported that the hygroscopicity of the introduced rubra-oak tree as per the tree production $11.5 \%$ on average at $40{ }^{\circ} \mathrm{C}$ and $90 \%$ relative humidity. Kim et al. (2017) reported no differences between hygroscopicity of domestic cork trees in indoor and outdoor environments. It was $12.2 \%$ on average at the $40{ }^{\circ} \mathrm{C}$ and relative humidity of $75 \%$ and $16.1 \%$ on average at the $40{ }^{\circ} \mathrm{C}$ and relative humidity of $90 \%$.

In the future, it will be necessary to investigate the hygroscopicity of major domestic species and to increase the number of samples for the study of regional anatomical and physical properties. These studies are expected to facilitate the efficient use of pine trees and breeding of species to be used as good materials.

\section{CONCLUSION}

In this study, moisture content, specific gravity, shrinkage and moisture absorption properties of pine trees in Goseong-gun, Hongcheon-gun and Bonghwagun were investigated. Air-dry moisture content and green moisture content are the same regardless of the tree production regions. Specific gravity of the heartwood part and the sapwood part of Bonghwa-gun pines was higher than that of the other two tree production regions. Goseong-gun pines in the heartwood part and Hongcheon-gun pines in the sapwood part were higher than the other when Goseong-gun and Hongcheon-gun pine trees were compared. Goseong-gun pine tree with higher specific gravity of heartwood part can be judged to be stronger than Hongcheon-gun pine tree as a whole. There was no difference in shrinkage regardless of the radial directions among the tree production regions. For the tangential direction, Bonghwa-gun pine and Hongcheon- gun pine trees were high in air-dry shrinkage, and Bonghwa-gun pine trees were high in total shrinkage, which was consistent with the order of the tracheid length. Hygroscopicity showed little difference between the tree production regions. We hope that based on the findings from this study, we can use pine efficiently and they will help to produce good varieties.

\section{REFERENCES}

Barber, N.F., Meylan, B.A. 1964. The anisotropic shrinkage of wood. Holzforschung 18(5): 146-156.

Cho, J.M. 1994. Wood properties and uses of the major tree species grown in Korea. Forestry Research Institute. Research Material No. 95. Seoul, Korea.

Haishi, T., Nakano, T., Kaburagi, J. 1973. Properties of the important Japanese woods physical properties(4)-On the moisture absorbability and swelling of the important Japanese woods-. BullGov. For. Exp. Sta. No. 256.

Han, G.S. 2015. Study on improvement site management syetem and supply system of timber for repairing culture properties. Cultural Heritage Administration. Daejeon. Korea.

Hiller, C.H. 1964. Pattern of variation of fibril angle within annual rings of Pinus attenuradiata. Res. Note FPL-034, U.S. Department of Agriculture, Forest Service, Forest Products Laboratory, Madison, Wisconsin.

Jo. J.M., Kang, S.G., Ahn, J.M., Lee, C.H., Jo, N.S., Shin C.S., Jung, H.S. 1982. On the wood properties of genus Pinus grown in Korea. Journal of the Korean Wood Science and Technology 10(3): 96-108.

Jung, S.H., Park, B.S. 2008. Wood properties of the useful tree species grown in Korea. National Institute of Forest Science, Seoul.

Kang, C.W., Kim, N.H., Kim, B.R., Kim, Y.S., B, H.S., Soe, W.T., Yoe,. H.M., Ho, S.W., Lee, W.H., Lee, 
H.Y. 2008. Wood physics and mechanical. Hyangmoonsa, Seoul Korea.

Kim, B.R., Akiyoshi, M. 1998. Studies on variability of wood properties in stem of Pinus koraiensis(2). Journal of the Korean Wood Science and Technology 26(2): 45-50.

Kim, B.R., Park, W.K., Choi, T.H. 2008. Properties od major Korean wood species for furniture manufacturing. Journal of the Korea Furniture Society 19(44): 365-374.

Kim, H.W., Byeon H.S., Kim, B.R. 2017. Physical and mechanical characteristics of Phellodendron amure Ruprecht. Journal of the Korean Wood Science and Technology 45(5): 519-524.

Kim, M.J., Seo, J.W., Kim, B.R. 2018. Anatomical characteristics of Korean red pines according to provinces. Journal of the Korean Wood Science and Technology 46(1): 100-106.

KS F 2199. 2001. Method of moisture content test for wood. Korean Standard Association.

KS F 2198. 2001. Method of specific gravity test for wood. Korean Standard Association.

KS F 2203. 2004. Method of shrinkage test for wood. Korean Standard Association.

KS F 2205. 2004. Method of hygroscopic test for wood.
Korean Standard Association.

Mark, R. E. 1967. Cell wall mechanics of tracheids. Yale Univ. Press, New Haven and London.National Institute of Forest Science.

Park, K.S., Kim, B.R. 2016. Wood quality and growth of Quercus rubra in Korea. Journal of Korea Furniture Society 27(2): 91-95.

Park, W.K., Lee, K.H. 2007. Changes in the Species of Woods Used for Korean Ancient and Historic Architecture. Journal of architectural history 50(1) Park, Y.G., Chang, Y.S., Yang, S.Y., Yeo, H.M., Lee, M.R., Eom, C.D., Kwon, O.K. 2015. Wood shrinkage measurement of using a flatbed scanner. Journal of the Korean Wood Science and Technology 43(1): 43-51.

Preston, R. D. 1952. The molecular architecture of plant cell walls. Chapman and Hall. London p.116.

Watanabe, H., Tsutsumi, J., Matsumoto, T., Ohta, S. 1964. Studies on juvenile wood. II. On distribution of specific compression strength and specific modulus of elasticity in st em of sugi tree (Crytomeria japonica D. Don). Mokazai Gakkaishi 10(4): 125-130.

Wellwood, R.W. 1962. Tensile testing of small wood sample. Pulp and Paper Magazine of Canada 63-61. 


\title{
APPENDIX
}

\author{
(Korean Version)
}

\section{한국산 소나무의 지역(고성, 홍천 및 봉화군)에 따른 물리적 특성}

요약 : 본 연구는 태백산맥을 기준으로 영동(고성군), 영서(홍천군), 영남(봉화군) 세 지역 간 소나무의 재질차이의 유무를 알기위해 물리적 특성을 조사하였다. 기건함수율 및 생재함수율(인위적)의 산지 간 차이를 보이지 않았다. 비중은 심재부와 변재부에서 봉화군 소나무가 두 산지보다 높았으며, 고성군과 홍천군 소나무 사이에는 심재부에서는 고성군 소나무가 높고 변재부에서는 홍천군 소나무가 고성군 소나무 보다 높게 나타났다. 심재부의 비중이 높게 나타난 고성군 소나무가 강도적으로 홍천군 소나무보다 클 것으로 판단된다. 수축율은 방사방향의 경우 산지 간 차이가 없고, 접선방향의 경우는 가도관장이 긴 봉화군 소나무가 높게 나타났다. 흡습율은 산지 간 차이가 거의 없는 것으로 나타났다. 이 결과로 소나무를 효율적으로 사용할 수 있고, 육종적으로 좋은 재질의 품종생산에도 도움이 될 것으로 생각한다.

\section{1. 서 론}

우리나라 소나무는 우수한 재질(물리적 및 역학적 성질) 특성을 가지고 있어, 예로부터 궁궐, 절, 한옥, 가구, 선박 등에 이용되어 온 우리민족의 대표적 수종이다. 또한 정서적으로 우리민족이 가장 좋아하는 나무로써 예로부터 우리나라 건축물 중 고려시대 $71 \%$, 조선중기 $73 \%$, 조선후기 $88 \%$ 에 이르는 사용량을 보였다(Park et al., 2007). 우리나라 소나무를 사용하는 대목장과 소목장에 의하면 생산 지역에 따라 소나무의 성질이 다르다고 하여(Han et al., 2015), 소나무를 효율적으로 이용하고, 육종적으로도 우수한 재질의 품종을 생산하기 위해서도 지역에 따른 성질이 다른 이유를 조사할 필요가 있을 거라고 생각하였다. 성질차이의 조사는 우선 기초적으로 조사할 수 있는 것이 해부학적, 물리적 및 역학적 성질일 것이다. 이에 본 연구자는 우리나라에서 소나무가 대표적으로 생산되는 영동(고성군), 영서(홍천군), 영남(봉화군) 3개 지역을 선정 해 샘플링 하여 해부학적 조사를 통해 지역에 따른 가도관 길이 및 가도관 직경에 대한 차이의 유무를 조사하였는데, 가도관 길이 및 가도관 직경에서 차이를 보이는 것으로 조사됐다(Kim et al., 2018).

따라서 본 연구에서는 전보의 한국산 소나무의 지역에 따른 해부학적 특성(Kim et al., 2018)에 이어 소나무의 생장 지역에 따른 물리적 성질 차이의 유무를 조사, 연구하는 것에 목적을 두었고, 목재의 물리적 성질은 기본적으로 해부학적 성질에 기인하기 때문에 이들의 결과와 함께 검토하였다.

\section{2. 재료 및 방법}

\section{1. 실험재료}

본 연구의 재료는 산림조합 동해목재유통센터에서 보유하고 있던 영동(고성군, Goseong-gun), 영서(홍천군, Hongcheongun), 영남(봉화군, Bonghwa-gun)지역의 소나무를 2015년에 1본씩 불하 받아 연구대상으로 하였다. 불하 시 두께 약 $20 \mathrm{~cm}$ 의 디스크상태였으며 이들의 수령, 흥고직경, 평균연륜폭 및 만재율은 Table 1(Kim et al., 2018)과 같고, 각 시편제작 은 Fig. 1(Park et al., 2015)과 같다. 또한 같은 연도 및 부위의 비교를 위해 연륜연대법을 이용해 벌채년도를 추정한 결과 고성 2014년, 홍천 2012년, 봉화 2014년으로 분석되었다(Kim et al., 2018).

\section{2. 실험방법}

\subsection{1. 함수율}

각 산지의 함수율은 생재함수율(인위적)과 기건함수율을 측정하였다. 생재함수율은 벌목 후 약 1 3년 경과된 시편을 불하 받아 측정할 수가 없어, 시편을 증류수에 침지시켜 무게의 차가 없을 때 까지 인위적으로 만들어 생재함수율로 측정하 였다. 각 산지의 시편의 크기는 $2 \mathrm{~cm}(\mathrm{~T}) \times 2 \mathrm{~cm}(\mathrm{R}) \times 2 \mathrm{~cm}(\mathrm{~L})$ 크기로 수로부터 연속으로 제작하였고, 이때 심재(5 8개)와 변재(4 6개)로 구분하였다(Fig. 1). 시편제조 및 측정은 KS F 2199(2001)에 준하였다. 


\subsection{2. 비중}

각 산지의 비중은 생재, 기건, 전건비중을 측정하였다. 시편의 크기는 $2 \mathrm{~cm}(\mathrm{~T}) \times 2 \mathrm{~cm}(\mathrm{R}) \times 2 \mathrm{~cm}(\mathrm{~L})$ 정사각형으로 수로부터 연속으로 제작하였다. 이때 심재(5 8개)와 변재(4 6개)로 구분하였다(Fig. 1). 시편제조 및 측정은 KS F 2198(2001)에 준하였다.

\subsection{3. 수축율}

각 산지의 수축율은 기건수축율과 전수축율을 측정하였다. $2 \mathrm{~cm}(\mathrm{~T}) \times 2 \mathrm{~cm}(\mathrm{R}) \times 2 \mathrm{~cm}(\mathrm{~L})$ 정사각형으로 수로부터 연속으로 제작하였다(11 14개). 시편의 길이 측정을 위하여 횡단면 상에 방사 및 접선 방향의 선을 그어 표시하여, 버니어캘리퍼스를 이용하여 측정하였다(Fig. 1). 시편제조 및 측정방법은 KS F 2203(2004)에 준하였다.

\subsection{4. 흡습율}

각 산지의 흡습율을 측정하기 위하여 시편의 크기는 $3 \mathrm{~cm}(\mathrm{~T}) \times 3 \mathrm{~cm}(\mathrm{R}) \times 0.5 \mathrm{~cm}(\mathrm{~L})$ 로 수로부터 연속으로 제작하였다 $(4 \sim 6$ 개). 제작 시에는 두 면을 곧은결면의 직육면체로, 짧은 축은 섬유방향에 평행으로 하였다(Fig. 1). 항온항습기(LHT-2250C, LabTech, Korea)에서 $40^{\circ} \mathrm{C}$, 상대습도 $75 \% / 40^{\circ} \mathrm{C}$, 상대습도 $90 \%$ 조건에 맞춰 무게 변화가 없을 때 까지 조습시켰다. 시편제조 및 측정방법은 KS F 2205(2004)에 준하였다.

\section{3. 결과 및 고찰}

\section{1. 함수율 및 비중}

Table 2는 고성군, 홍천군, 봉화군 각 지역의 소나무의 기건함수율 및 생재함수율을 나타낸 것이다. 기건함수율은 심재부 에서 고성군 소나무가 $13.7 \%$, 홍천군 소나무가 $12.4 \%$, 봉화군 소나무가 $13.9 \%$ 변재부에서는 고성군 소나무가 $14.0 \%$, 홍천군 소나무가 $12.5 \%$, 봉화군 소나무가 $13.8 \%$ 로 측정되었다. 생재함수율은 심재부에서 고성군 소나무가 $71.4 \%$, 홍천군 소나무가 $76.9 \%$, 봉화군 소나무가 $90.9 \%$, 변재부에서는 고성군 소나무가 $166.7 \%$, 홍천군 소나무가 $134.4 \%$, 봉화군 소나무 가 $110.3 \%$ 로 측정되었다. 산지 간 차이 유무를 위해 던컨테스트를 실시한 결과 기건함수율은 변재부에서 홍천군 소나무가 $12.5 \%$ 로 고성군 소나무가 $14.0 \%$, 봉화군 소나무가 $13.8 \%$ 보다 적은 것으로 나타났고, 기건함수율 심재와 생재함수율 심재와 변재에서는 지역 간 차이가 없는 것으로 나타났다. Jo et al.(1982)은 소나무 속의 재질에 관한 시험에서 심, 변재 구분 없이 생재함수율은 잣나무 $84 \%$, 소나무 94\%, 곰솔 $91 \%$, 강송 $91 \%$ 로 보고하고 있는데 아마 심재부의 생재함수율로 추정되며 이 값들은 본 연구의 인위적 생재함수율인 심재부와 비슷한 것으로 나타났다. Kang et al.(2008)은 생재함수율은 수종에 따라 많은 차이를 보이지만 대부분 수종의 생재함수율은 30 200\%이라 나타냈으며, 우리나라의 평균 기건함수율은 방습의 경우 평균 $14.2 \%$, 흡습의 경우 $13.2 \%$ 로 보고하고 있다. Kim et al.(2008)은 기건함수율이 전북 무주산 소나무 심재 $12.7 \%$, 변재 $10.3 \%$ 안면도소나무의 경우 심재 $10.9 \%$, 변재는 $10.7 \%$ 를 나타냈다. 본 실험과 비교했을 때 고성, 홍천, 봉화군의 소나무가 무주 및 안면도 소나무보다 높은 기건 함수율을 나타냈다.

Table 3은 고성군, 홍천군, 봉화군 지역별 전건, 기건 및 생재비중을 나타낸 것이다. 전건비중 중 심재부는 고성군 소나무 가 0.45 , 홍천군 소나무가 0.40 , 봉화군 소나무가 0.46 , 변재부는 고성군 소나무가 0.37 , 홍천군 소나무가 0.41 , 봉화군 소나무가 0.45 으로 측정되었다. 통계적으로 심재부는 고성군과 봉화군 소나무가 높게 나타났고 홍천군 소나무가 낮게 나타났다. 변재부는 봉화군 소나무가 가장 높고 다음으로 홍천군 소나무가, 고성군 소나무 순으로 나타났다. 기건비중 중 심재부는 고성군 소나무가 0.47 , 홍천군 소나무가 0.42 , 봉화군 소나무가 0.49 변재부는 고성군 소나무가 0.40 , 홍천군 소나무가 0.44 , 봉화군 소나무가 0.48 로 측정되었다. 통계적으로 심재부에서는 전건비중과 같은 경향으로 고성군과 봉화군 소나무가 높게 나타났고, 변재부는 봉화군 소나무가 높게 나타났다. 생재비중 중 심재부는 고성군 소나무가 0.48 , 홍천군 소나무가 0.44, 봉화군 소나무가 0.54, 변재부는 고성군 소나무가 0.42, 홍천군 소나무가 0.46, 봉화군 소나무가 0.51로 측정되었다. 통계적으로 심재부에서는 봉화군 소나무가 가장 높게 나타났고, 고성군과 홍천군 소나무는 차이가 없는 것으로 나타났다. 변재부에서 봉화군 소나무가 가장 높고 다음으로 홍천군, 고성군 소나무 순으로 나타났다. 전반적으로 심재부에서 
Physical Characteristics of Korean Red Pines According to Provinces (Goseong, Hongcheon and Bonghwa-gun)

봉화군 소나무가 두 산지보다 높았으며, 특히 변재부에서 두 산지보다 확연히 높게 나타났다. 고성군과 홍천군 소나무 사이에는 심재부에서는 고성군 소나무가 높고 변재부에서는 홍천군 소나무가 고성군 소나무보다 높게 나타났으나 심재부가 높게 나타난 고성군 소나무의 비중이 높다고 판단할 수 있을 것으로 생각한다. 따라서 심재부의 비중이 높게 나타난 고성군 소나무가 전체적으로 홍천군 소나무보다 강도가 클 것으로 예상 할 수 있을 것으로 생각된다. Kim et al.(2008)은 전북 무주군 소나무의 기건비중(심재, 변재) 및 생재비중(심재, 변재) 각각 $0.49,0.43$ 및 $0.40,0.40$ 안면도 소나무의 경우 0.44 , 0.45 및 $0.40,0.40$ 춘양목의 경우 0.45, 0.45 및 0.51, 0.45 라고 보고하였다. Jung et al.(2008)의 한국산 유용수종의 목재성질에서 소나무의 기건비중 0.47 , 전건비중 0.44으로 보고하였다. 또한 Cho (1994)는 소나무의 생재비중을 0.70 , 기건비중을 0.47 로 나타냈는데 생재비중은 질량을 생재중량으로 한 것으로 판단 되 본 연구의 생재비중(전건질량)과는 비교가 어려울 것으로 판단된다. 이 들 보고들은 고성산과 홍천산과 비슷한 값을 보였다.

\section{2. 수축율}

Table 4는 고성군, 홍천군, 봉화군 지역 소나무의 기건수축율, 전수축율 및 $\mathrm{T} / \mathrm{R}$ 율을 나타낸 것이다. 기건수축율의 접선방 향의 경우 고성군 소나무가 $2.86 \%$, 홍천군 소나무가 $3.94 \%$, 봉화산군 소나무가 $4.39 \%$ 로 측정되었고, 방사방향의 경우 고성군 소나무가 $1.73 \%$, 홍천군 소나무가 $2.09 \%$, 봉화군 소나무가 $2.29 \%$ 로 측정되었다. T/R비는 고성군 소나무가 $1.67 \%$, 홍천군 소나무가 $1.89 \%$, 봉화군 소나무가 $1.92 \%$ 로 측정되었다. 전수축율의 접선방향의 경우 고성군 소나무가 $6.32 \%$, 홍천군 소나무가 $6.58 \%$, 봉화군 소나무가 $9.85 \%$ 로 측정되었고, 방사방향의 경우 고성군 소나무가 $2.83 \%$, 홍천군 소나무가 $3.44 \%$, 봉화군 소나무가 $3.68 \%$ 로 측정되었다. $\mathrm{T} / \mathrm{R}$ 비는 고성군 소나무가 $2.11 \%$, 홍천군 소나무가 $1.04 \%$, 봉화군 소나무가 $2.68 \%$ 로 측정되었다. 산지 간 유의차를 알기 위해 던컨테스트를 실시한 결과 접선방향의 기건수축 율은 홍천군 소나무가와 봉화군 소나무가 높게 나타났으며, 전수축율은 봉화군 소나무가 높게 나타났고 방사방향은 산지 간 차이가 없는 것으로 나타났다. Fig. 2는 세 산지에서 가도관장(Kim et al., 2018)과 수축율과의 관계를 나타낸 것이다. 그림에서 보면 수축율과 가도관장은 비례관계가 있는 것으로 나타났다. Kim et al.(1998), Hiller(1964), Mark(1967),

Preston(1952), Wellwood(1962), Wadanabe et al.(1964) 등은 가도관장과 마이크로피브릴경각과는 부의 관계가 있는 것으 로 보고하였다. 즉 가도관장이 길면 마이크로피브릴경사각이 작아지고, 가도관장이 짧아지면 마이크로피브릴경사각이 커 진다고 하였다. Barber et al.(1964)은 마아크로피브릴경사각이 증가하면 섬유방향 수축율이 증가하고, 마아크로피브릴 경사각이 감소하면 횡방향 수축율이 감소한다고 하였다. 본 연구에서 봉화군 소나무에서 횡방향 수축율이 큰 것은 가도관장 이 길기 때문이라고 생각할 수 있다. 이를 더욱 입증하기위해서는 앞으로 이들의 마이크로피브릴경사각의 조사가 필요할 것으로 생각한다.

Kim et al.(2008)은 안면도 소나무의 T/R율을 2.91로 나타냈다. 본 실험과 비교결과 고성군, 홍천군, 봉화군 소나무가의 $\mathrm{T} / \mathrm{R}$ 율보다 안면도 소나무의 T/R율이 크게 나타났다. Cho(1994)는 소나무 수축율은 전수축율에서 방사방향이 $4.88 \%$, 접선방향이 9.11\%, 섬유방향이 $0.31 \%$ 로 방사방향은 세지역보다 높고, 접선은 고성군, 홍천군 소나무보다 높고, 봉화군 소나무보다는 낮은 값을 보였다. 기건 수축율은 방사방향이 $2.97 \%$, 접선방향이 $5.40 \%$, 섬유방향이 $0.16 \%$ 로 세 지역 보다 높은 값을 나타냈다.

\section{3. 흡습율}

Table 5 는 고성군, 홍천군, 봉화군 세지역 소나무의 흡습율을 나타낸 것이다. 각 지역의 흡습율은 $40^{\circ} \mathrm{C}$ 상대습도 $75 \%$ 의 흡습율의 경우 고성군 소나무가 $13.0 \%$, 홍천군 소나무가 $13.0 \%$, 봉화군 소나무가 $13.3 \%$ 로 봉화군 소나무가 높게 나타났으 며, $40^{\circ} \mathrm{C}$ 상대습고 $90 \%$ 의 흡습율의 경우 고성군 소나무가 $16.9 \%$, 홍천군 소나무가 $16.7 \%$, 봉화군 소나무가 $16.9 \%$ 로 산지 간 차이가 없는 것으로 나타났다. Haishi et al.(1973)은 일본산 주요수종의 평형함수율에 대한 연구에서 온도 $40^{\circ} \mathrm{C}$ 상대습도 $75 \%$ 시 9.7 13.7\%범위로 심재의 겨우 평균 $12.3 \%$ 변재의 경우 $12.4 \%$, 온도 $40^{\circ} \mathrm{C}$ 상대습도 $90 \%$ 시 14.3 19.2\%범위로 심재의 경우 $17.4 \%$ 변재의 경우 $17.8 \%$ 로 보이는 것으로 보고하고 있다. 국내산 소나무는 일본산 주요 
수종의 평균 흡습율보다 높은 수준인 것으로 나타났다. Park et al.(2016)은 도입산 루브라참나무의 산지 별 흡습율을 $40^{\circ} \mathrm{C}$ 상대습도 $75 \%$ 에서 평균 $11.5 \%$ 로 $40^{\circ} \mathrm{C}$ 상대습도 $90 \%$ 에서 $15.4 \%$ 로 보고하였고, Kim et al.(2017)은 국내산으로 황벽나무의 실내와 야외에 방치한 것에 대해 실내와 야외에서 차이가 없었으며 $40^{\circ} \mathrm{C}$ 상대습도 $75 \%$ 에서 평균 $12.2 \%$ 로 $40^{\circ} \mathrm{C}$ 상대습도 $90 \%$ 에서 $16.1 \%$ 로 보고한 정도이다. 앞으로 국내산 주요 수종에 대한 흡습율의 조사가 필요할 것으로 생각한다. 앞으로 지역별 해부학적 및 물리적 성질에 대해 샘플수를 늘려 조사 할 필요가 있을 것으로 판단된다. 이러한 조사들은 소나무를 효율적으로 사용할 수 있고, 육종적으로 좋은 재질의 품종생산에도 도움이 될 것으로 생각한다.

\section{4. 결 론}

본 연구에서는 태백산맥을 기준으로 영동(고성군), 영서(홍천군), 영남(봉화군)지역 간 소나무의 재질차이의 유무를 알기 위해 함수율, 비중, 수축율 및 흡습성 특성을 조사하였다. 기건함수율 및 생재함수율은 산지 간 차이를 보이지 않았다. 비중은 심재부와 변재부에서 봉화군 소나무가 두 산지보다 높았으며, 고성군과 홍천군 소나무 사이에는 심재부에서는 고성군 소나무가 높고 변재부에서는 홍천군 소나무가 높게 나타났다. 심재부의 비중이 높게 나타난 고성군 소나무가 전체적 으로 홍천군 소나무보다 강도가 클 것으로 판단 할 수 있을 것으로 생각된다. 수축율은 방사방향의 경우 산지 간 차이가 없는 것으로 나타났다. 접선방향의 경우는 기건수축율에서 봉화군 소나무와 홍천군 소나무가 높고 전수축율에서 봉화군 소나무가 높게 나타났는데, 이는 가도관장 길이순과 같았다. 흡습율은 산지 간 차이가 거의 없는 것으로 나타났다. 이 결과로 소나무를 효율적으로 사용할 수 있고, 육종적으로 좋은 재질의 품종생산에도 도움이 될 것으로 생각한다. 